\title{
Axotomy-Induced Alterations in the Synthesis and Transport of Neurofilaments and Microtubules in Dorsal Root Ganglion Cells
}

\author{
M. M. Oblinger ${ }^{1}$ and R. J. Lasek ${ }^{2}$ \\ ${ }^{1}$ Department of Biological Chemistry \& Structure, Chicago Medical School, North Chicago, Illinois 60064, and \\ ${ }^{2}$ Bioarchitectonics Center, Case Western Reserve University School of Medicine, Cleveland, Ohio 44106
}

\begin{abstract}
Changes in the synthesis and axonal transport of neurofilament (NF) proteins and tubulin were examined after various selective axotomies of adult rat DRG cells. For axonal transport studies, DRGs were labeled by microinjection of ${ }^{35}$ S-methionine $14 \mathrm{~d}$ after axonal injuries, and nerves were retrieved 7 or $14 \mathrm{~d}$ after labeling. Slowly transported proteins were examined by quantitative PAGE/fluorography. After
\end{abstract} distal peripheral nerve crush (50-55 $\mathrm{mm}$ from the DRG), the cytoskeleton that entered undamaged regions of peripheral branch DRG axons by slow axonal transport differed from normal, while the cytoskeleton that entered dorsal root axons did not. Specifically, smaller-than-normal ratios of labeled NF protein/tubulin were transported in peripheral DRG axons after distal peripheral nerve crush. This change was almost entirely due to a selective decrease in the output of labeled NF proteins rather than to an increase in the amount of tubulin transported with NF proteins. Since the efficiency of axonal regeneration is known to be lower after cut injury than after nerve crush, we compared the effect of cut versus crush axotomy of peripheral DRG axons on cytoskeletal protein output. A more substantial reduction in the labeled NF/ tubulin transport resulted in peripheral DRG axons if the distal sciatic nerve was cut rather than crushed but, even under these axotomy conditions, the labeled NF/tubulin ratios in dorsal root axons were not reduced. Peripheral cut axotomy did result in a lag in the advance of the labeling peak of the NF/microtubule protein wave in dorsal root axons, suggesting either that these proteins were delayed in exiting the cell body or that a slowing of the rate of their transport occurred. Pulse-labeling DRGs in vitro using ${ }^{35}$ S-methionine, and analysis of labeled proteins by 2-dimensional PAGE-fluorography demonstrated that the incorporation of radioactivity into NF proteins was significantly reduced, while the labeling of tubulins was unchanged $14 \mathrm{~d}$ after distal peripheral axotomy. In contrast to the results of peripheral axotomy, dorsal root crushes made close to the DRG (2-3 $\mathrm{mm}$ ) or considerably distal (at the CNS entry zone 28-30 mm from the DRG) did not produce detectable changes in the amount of labeled NF or tubulin transport in central or

\footnotetext{
Received June 17, 1987; revised Sept. 24, 1987; accepted Sept. 29, 1987.

This work was supported by grants from the NINCDS and the Schweppe Foundation (to M.M.O.) and by grants from the NINCDS and the NIA (to R.J.L.). We thank Shirley Ricketts, Diane Filsinger, and Judith Pickett for their excellent technical assistance.

Correspondence should be addressed to Dr. Monica M. Oblinger, Department of Biological Chemistry \& Structure, The Chicago Medical School, 3333 Green Bay Road, North Chicago, IL 60064.

Copyright $(\mathrm{C} 1988$ Society for Neuroscience $0270-6474 / 88 / 051747-12 \$ 02.00 / 0$
}

peripheral branch axons. These findings indicate that the down-regulation of NF production/output that is exhibited at $14 \mathrm{~d}$ after peripheral branch axotomy is not present after central branch injury. In addition, our findings demonstrate that a change in cell body synthesis of NF proteins does not affect the cytoskeletal networks of both axonal branches of the DRG cell equally. These observations lend support to the hypothesis that the cytoskeletal networks of the 2 axons are somewhat segregated at their origin in the DRG cell body.

Neurons from a variety of regions of the nervous system respond to axonal injury by undergoing metabolic change. Alterations in the neuronal cytoskeleton appear to comprise a large component of the metabolic response to axonal injury. For example, decreased amounts of neurofilament (NF) proteins and tubulins are axonally transported in slow component a (SCa) and increased amounts of tubulins are transported in slow component b $(\mathrm{SCb})$ in intact portions of motor axons after distal sciatic nerve injury in rats (Lasek and Hoffman, 1976; Hoffman and Lasek, 1980). In injured ventral roots of frogs, the levels of NF protcin and tubulin decrease significantly in axonal segments proximal to the injury (Sinicropi and Mcllwain, 1983). Changes in the levels of NF protein transport are believed to be largely responsible for axonal atrophy after injury, since NFs are a primary determinant of axonal diameter (Lasek et al., 1983; Hoffman et al., 1985). The studies of protein transport and protein content in injured axons cited above have suggested that NF and tubulin synthesis are altered in the perikarya of axotomized neurons. In fact, several studies have provided fairly direct evidence for changes in tubulin synthesis after axotomy (Heacock and Agranoff, 1976; Burrell et al., 1980; Guilian et al., 1980; Perry and Wilson, 1981; Hall, 1982; Neumann et al., 1983), and 2 recent studies have demonstrated a change in the mRNA levels for the $68 \mathrm{kDa}$ NF subunit (NF68) in axotomized DRG neurons using in situ hybridization (Hoffman et al., 1987; Wong and Oblinger, 1987). These studies suggest that changes in translation and probably transcription of cytoskeletal protein genes are important components of the neuronal injury response.

A change in the level of perikaryal synthesis is not the only mechanism by which the level of axonal proteins could change after injury. Failure of proteins to exit from the cell body or changes in transport rate in axons could also result in alterations in the axonal levels of particular proteins. An increase in NFs in the neuronal cell bodies of axotomized neurons has been 


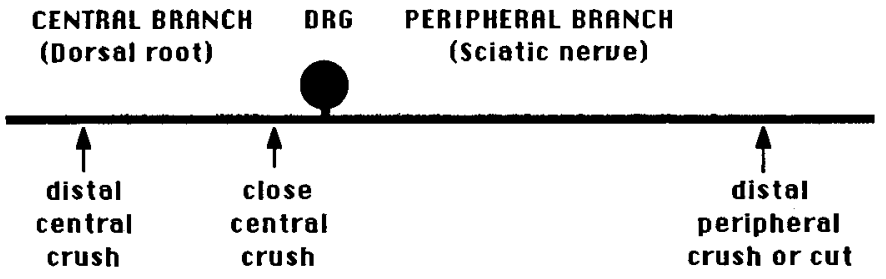

Figure 1. Schematic of the L5 DRG system illustrating the location of the various axotomies used in the experiments. The distal peripheral site is $\mathbf{5 0 - 5 5} \mathrm{mm}$ from the DRG, the distal central site is $28-30 \mathrm{~mm}$ away, and the close central site is $2-3 \mathrm{~mm}$ from the DRG.

documented using morphological (Pannese, 1963; Price and Porter, 1972; Torvik, 1976), biochemical (Sinicropi and McIlwain, 1983) and immunocytochemical (Moss and Lewkowicz, 1983; Drager and Hofbauer, 1984) methods. The observations that increases in perikaryal NF content occur in conjunction with decreases in axonal NF levels indicate that the cytoskeletal alterations in injured neurons are the outcome of a response more complex than just a change in protein synthesis. A recent study has suggested that the increase in immunocytochemically detectable NFs (particularly phosphorylated NFs) in the perikarya of axotomized DRG neurons may be the result of failure of NFs to exit from the cell body (Goldstein et al., 1987). Thus, while changes in cell body synthesis may be a primary factor in determining the levels of axonal proteins, the gating of proteins from the cell body into the axon by yet undefined mechanisms may also play an important role in the injury response.

The DRG cell is an ideal system in which to examine protein synthesis and protein gating or routing after axotomy because it has 2 distinct axonal branches, each of which appears to maintain a distinct relationship to the cell body. Many of the structural and functional properties, including axonal diameter, amount and rate of cytoskeletal protein transport, and regeneration rate differ in the central and peripheral axonal branches of DRG cells (Mori et al., 1979; Wujek and Lasek, 1983; Oblinger and Lasek, 1984, 1985; Suh et al., 1984). In addition, we have shown that a previous conditioning lesion of the peripheral axon of DRG cells will increase the rate of regeneration of the peripheral axon, but not of the central axon in response to a subsequent axotomy (Oblinger and Lasek, 1984). The conditioning lesion phenomenon suggests that mechanisms exist that enable a selective change in the properties of one axonal branch of the DRG cell to occur without a concordant change in the other axon. Synthesis, export from the cell body, and axonal transport of cytoskeletal proteins are levels at which such a nonconcordant change might occur. The DRG cell is also an interesting model for axotomy studies because of reports that chromatolysis and changes in protein synthesis are more pronounced in DRG perikarya after peripheral than after central axon injury (reviewed in Cragg, 1970, and Lieberman, 1971; Hall, 1982).

In the present study, we were specifically interested in the following questions: How does axotomy of peripheral versus central branch DRG axons affect NF and tubulin synthesis and transport in the DRG cell? Does the axonal transport of NF and tubulin proteins change coordinately in both axonal branches of the DRG cell after various axotomies? In assessing these questions, we examined both cut and crush axotomy conditions and lesions located close and distal to the DRG. We provide evidence that the cytoskeletal response of the DRG cell is mark- edly different after peripheral injury than after central branch injury. We also demonstrate that a change in the cytoskeleton of one axon of the DRG cell can occur without a concordant change in the other axon. Last, we document our finding that the effect of cut injury on NF/tubulin transport into DRG axons is more pronounced than is the effect of crush injury.

\section{Materials and Methods}

Nerve injury. Adult male Sprague-Dawley rats (250-300 gm) were anesthetized by intraperitoneal injection of Chloropent (Fort Dodge Laboratories, Fort Dodge, IA) at a dose of $3 \mathrm{ml} / \mathrm{kg}$. Peripheral axons of L5 DRG neurons were injured by either crushing (majority of the experiments) or cutting the distal sciatic nerve (typically $50-55 \mathrm{~mm}$ from the DRG; Fig. 1). The crush axotomy involved exposing the sciatic nerve and crushing it 3 consecutive times for $30 \mathrm{sec}$ with \#5 Dumont forceps; the cut axotomy involved severing the nerve with scissors. Central branch axons of L5 DRG neurons were injured at one of 2 levels (Fig. 1). In the distal central crush condition, the L5 dorsal root was exposed by partial laminectomy at its level of entry into the spinal cord (typically 28-30 $\mathrm{mm}$ from the DRG) and three $30 \mathrm{sec}$ crushes were applied to the nerve with \#5 Dumont forceps. In the close central crush condition, the L5 dorsal root was exposed near the L5 DRG (typically 2-3 mm from the ganglion) and crushed as described. Axotomy surgeries preceded procedures for radiolabeling proteins in DRG neurons by 1 $14 \mathrm{~d}$.

Metabolic labeling of axonally transported proteins. Animals were anesthetized with Chloropent and the L5 DRG was exposed by a partial laminectomy. Two $\mu \mathrm{l}$ of saline containing $500 \mu \mathrm{Ci}$ of ${ }^{35} \mathrm{~S}$-methionine (New England Nuclear, Boston, MA) was injected into the midpoint of the DRG at a rate of $0.1 \mu \mathrm{l} / \mathrm{min}$ using a glass micropipette. During the injection, the animal's spinal column was stabilized with large forceps anchored to magnetic base Fleximounts (Stoelting Co., Chicago, IL). Rats were killed 7 or $14 \mathrm{~d}$ after the injection and the entire $\mathrm{L} 5$ nerve system was removed and rapidly frozen. Consecutive $2 \mathrm{~mm}$ sections of frozen nerve were cut using a Mickel gel slicer (Brinkmann Instruments) and solubilized by homogenization in $200 \mu \mathrm{l}$ of SUB $(0.5 \%$ SDS, $8 \mathrm{M}$ urea, $2 \%$ beta-mercaptoethanol) in small glass-glass homogenizers. The samples werc centrifuged at $17,000 \times \mathrm{g}$ for $10 \mathrm{~min}$ to pellet insoluble material and the radioactivity in $10 \mu \mathrm{l}$ aliquots of the supernates was measured by liquid-scintillation counting. The remainder of each supernate was frozen at $-70^{\circ} \mathrm{C}$ until used for gel electrophoresis.

Radiolabeling newly synthesized DRG proteins. For in vitro labeling, L5 DRGs were removed from rats 1-14 d after nerve injury and desheathed. Ventral roots were dissected away from the bottom of the ganglia; dorsal roots and peripheral nerves were trimmed very close to the DRGs. Each DRG was placed in $0.5-1 \mathrm{ml}$ of a methionine-free MEM (Minimal Essential Media) solution made using a Select-Amine Kit with Hanks' salt (Gibco, Grand Island, NY). The DRGs were allowed to equilibrate at $37^{\circ} \mathrm{C}$ for $20 \mathrm{~min}$ in this solution with bubbling $95 \%$ oxygen. Next, the DRGs were place in $0.5 \mathrm{ml}$ of fresh MEM solution containing $250 \mu \mathrm{Ci}$ of ${ }^{35} \mathrm{~S}$-methionine and incubated for $1 \mathrm{hr}$ at $37^{\circ} \mathrm{C}$ with bubbling 95\% oxygen. Prcliminary studies established that the incorporation of labeled methionine into protein remained linear for nearly $4 \mathrm{hr}$ under these conditions.

In several experiments, L5 DRGs were labeled in vivo by microinjection of $250 \mu \mathrm{Ci}$ of ${ }^{35} \mathrm{~S}$-methionine dissolved in $1 \mu \mathrm{l}$ of saline, using a glass micropipette. Animals were decapitated $1 \mathrm{hr}$ later and the labeled DRGs were rapidly removed. For both in vitro and in vivo preparations, labeling was terminated by rinsing the DRGs in ice-cold saline and homogenizing each ganglion in $200 \mu \mathrm{l}$ of $50 \mathrm{~mm}$ sodium phosphate, $\mathrm{pH}$ 8 . From each homogenate, aliquots were removed, frozen, and subsequently used to determine total ganglion protein using a standard fluorescamine assay. The remainder of the sample was brought to $1 \%$ SDS; aliquots were used to determine the amount of radiolabeled acid-precipitable protein and the rest of the sample was used for gel electrophoresis.

Gel electrophoresis. SDS-PAGE/fluorography was used to analyze axonally transported proteins. Samples of labeled dorsal root and sciatic nerve axons, progressing from the DRG distally, were loaded into consecutive wells of 14-comb slab gels. The $1.5 \mathrm{~mm}$ gels contained a gradient of $6-17.5 \%$ polyacrylamide with a $4 \%$ stacking gel, and were run using Laemmli (1970) buffer at $10 \mathrm{~W} /$ gel. Molecular-weight marker proteins were from Sigma, with the following $M_{\mathrm{r}}$ values: myosin, 205,000; 


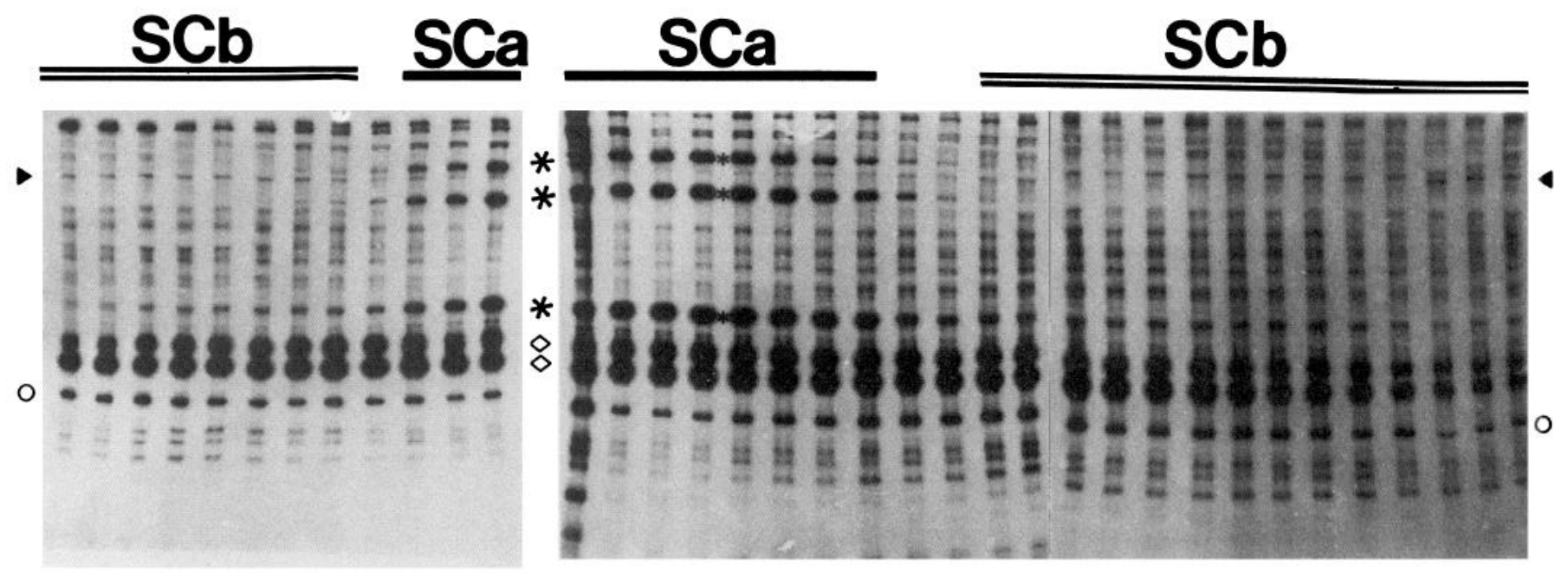

\section{SCa}
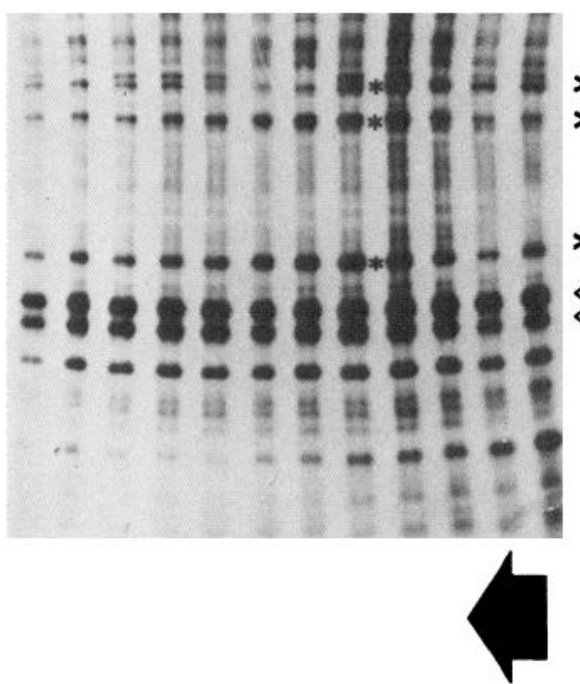

SCa
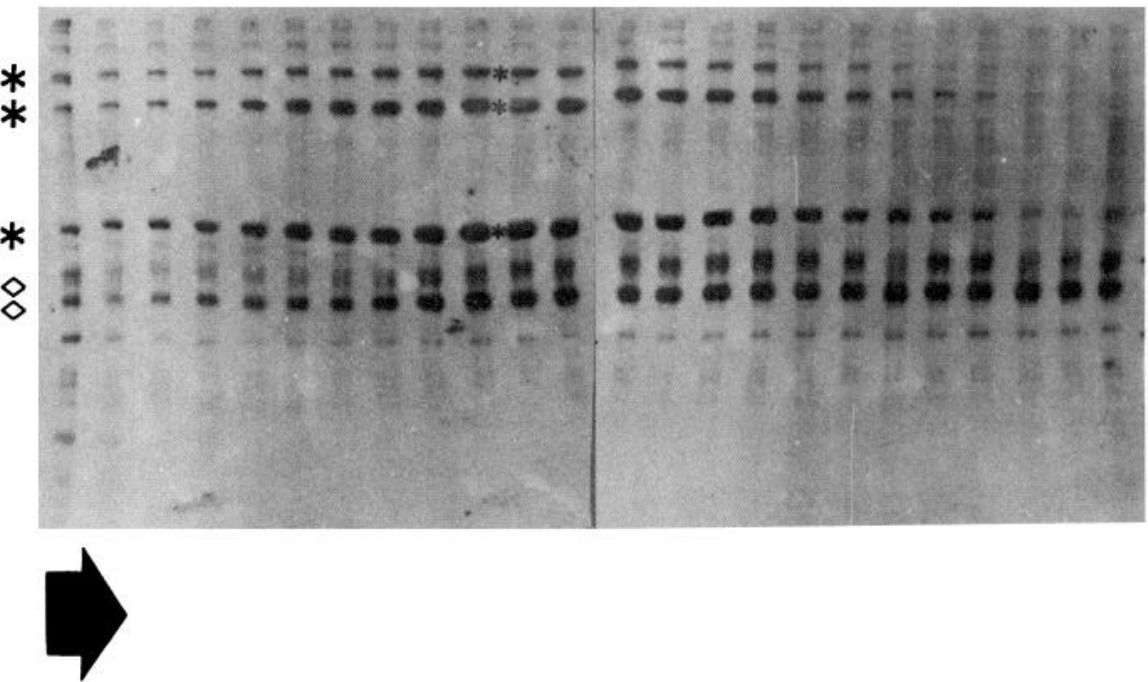

Figure 2. Fluorographs of slow transport profiles in bifurcating axons of DRG cells. Labeled proteins present $7 \mathrm{~d}$ (top panels) and $14 \mathrm{~d}$ (bottom panels) following injection of ${ }^{35} \mathrm{~S}$-methionine into L5 DRGs. The pairs of gel panels on the right side of the large arrows show labeled proteins present in consecutive $2 \mathrm{~mm}$ sections of peripheral branch DRG axons located in the sciatic nerve. The lanes in these gels represent nerve samples progressing distally from the DRG from left to right. The gel panels on the left side represent consecutive $2 \mathrm{~mm}$ sections of central branch DRG axons located in the L5 dorsal root. The lanes represent nerve samples progressing distally from the DRG from right to left, as indicated by the large arrows at the bottom of the figure. NF protein bands (large asterisks), alpha- and beta-tubulins (open diamonds), actin (open circle), and clathrin (solid arrowhead) are indicated. The small asterisks within the gel panels indicate apparent peaks of labeled NF proteins (in SCa) in different nerves. Note that the labeled proteins associated with both slow component a $(S C a)$ and slow component b $(S C b)$ move through peripheral branch sensory axons more quickly than they move through central branch sensory axons.

phosphorylase b, 97,000; BSA, 68,000; pyruvate kinase, 57,000; ovalbumin, 43,000; and lysozyme, 14,000.

Two-dimensional (2D) PAGE/fluorography was used to analyze newly synthesized DRG proteins. DRG samples were diluted 4-6 times with lysis buffer [ $8 \%$ Triton X-100, 9 m urea, $5 \%$ beta-mercaptoethanol, and 5\% Ampholines (LKB Instruments), $\mathrm{pH} 3.5-10$ and $\mathrm{pH} 5-7$, mixed in a ratio of 1:3] prior to isoelectric focusing. Tube gels were run for $7000 \mathrm{~V}$-hr using the O'Farrell (1975) procedure. The isoelectric focusing gels were then removed from the guide tubes, loaded onto slab gels, and run in the second dimension as described above.

After electrophoresis, gels were stained with $0.1 \%$ Coomassie blue G-250 (Sigma), destained, and prepared for fluorography (Bonner and Laskey, 1974) to visualize labeled polypeptides. Briefly, gels were processed through dimethyl sulfoxide (DMSO), impregnated with 2,5-diphenyl oxazole (PPO)-DMSO, rehydrated, dried between dialysis mem- branes, and exposed to preflashed x-ray film at $-70^{\circ} \mathrm{C}$

Quantitation of labeled proteins. Fluorographs were used as guides to locate and excise proteins from gels. The gel pieces were placed in $6 \mathrm{ml}$ plastic scintillation vials and dissolved in $750 \mu \mathrm{l}$ of $30 \%$ hydrogen peroxide at $60^{\circ} \mathrm{C}$ for $48 \mathrm{hr}$. Cocktail (Formula 963; New England Nuclear) was added to each vial and the radioactivity in each sample was determined by scintillation counting. The counts were corrected for background, isotope decay, and converted to disintegrations per minute (dpm). Data from different animals were normalized to allow calculation of means and thus comparisons between different conditions. Data were expressed either as a ratio of the $\mathrm{dpm}$ in NF proteins/tubulins, as a ratio of the dpm in a particular protein/total labeled protein in the sample, or as specific activity (dpm/ $\mu \mathrm{g}$ protein). Where statistical significance is indicated, this was assessed using Student's 2-tailed $t$ test at the $95 \%$ confidence level. 


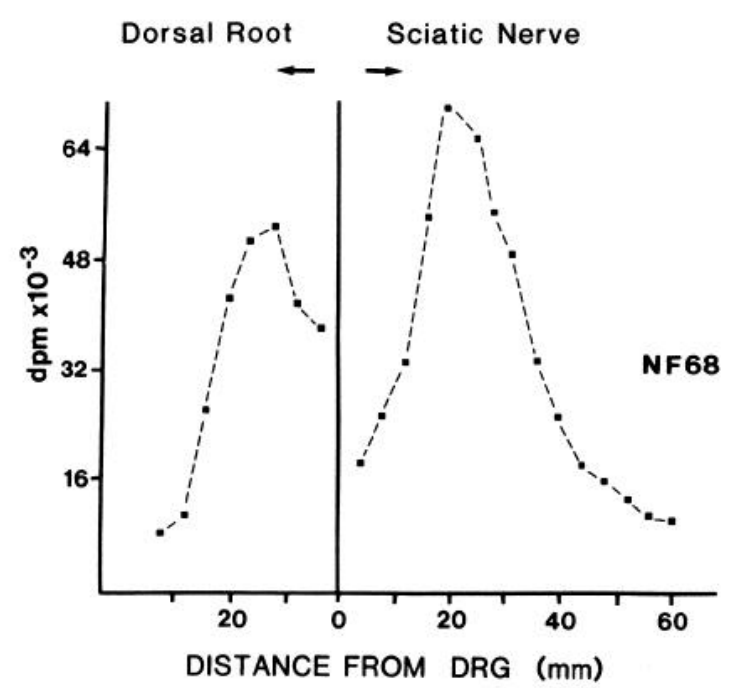

Figure 3. Quantitation of NF protein transport in central and peripheral branch sensory axons. Axonal samples located in the dorsal root and sciatic nerves were obtained $14 \mathrm{~d}$ after labeling the L5 DRG with ${ }^{35} \mathrm{~S}$-methionine and subjected to PAGE/fluorography. The NF68 protein band was excised from consecutive gel lanes using fluorographs as guides, and the radioactivity determined. Note that the peak of the labeling wave is further from the DRG in peripheral than in central DRG axons of the same animal. Also, more labeled NF68 protein is present in peripheral than in central DRG axons.

\section{Results}

\section{Cytoskeletal protein transport in normal bifurcating DRG} axons

Fluorographs of labeled proteins in consecutive axonal samples obtained from normal dorsal roots and sciatic nerves 7 and 14 d after labeling L5 DRGs are shown in Figure 2. Each of the 2 slow components of axonal transport ( $\mathrm{SCa}$ and $\mathrm{SCb}$ ) was distinguishable in both dorsal root and sciatic nerve axons by its distinct polypeptide composition. For example, labeled NF triplet proteins $(200,145$, and $68 \mathrm{kDa})$ defined the SCa wave of transport, while a more complex group of labeled proteins that included clathrin, actin, and many other proteins defined the faster $\mathrm{SCb}$ wave of transport (Fig. 2). In normal DRG axons, SCa conveyed a substantial amount of tubulin, but some labeled tubulin was also conveyed in SCb (Fig. 2; see also Tashiro et al., 1984; Oblinger, 1985; Oblinger et al., 1987).

Our analysis of normal DRG cells confirmed that central and peripheral branch axons differed in both the rates of slow transport and the amounts of labeled proteins transported (Mori et al., 1979; Wujek and Lasek, 1983). The rate differences were visually apparent when the distances from the DRG at which various labeled proteins were located in dorsal root and sciatic nerve axons at different times after labeling were compared (Fig. 2 ). When radioactivity in individual protein bands was plotted as a function of distance from the DRG, a bell-shaped labeling curve could be visualized for many proteins. Figure 3 illustrates such a plot for the $68 \mathrm{kDa}$ NF protein (NF68) in DRG axons. Note that the peak of the wave is located further from the DRG in peripheral axons than it is in dorsal root axons of the same

Figure 4. Fluorographs of labeled proteins present in consecutive 2 mm segments of peripheral branch DRG axons $7 \mathrm{~d}$ after labeling the L5 DRG with ${ }^{35}$ S-methionine. $A$, Normal system. $B$, Distal peripheral
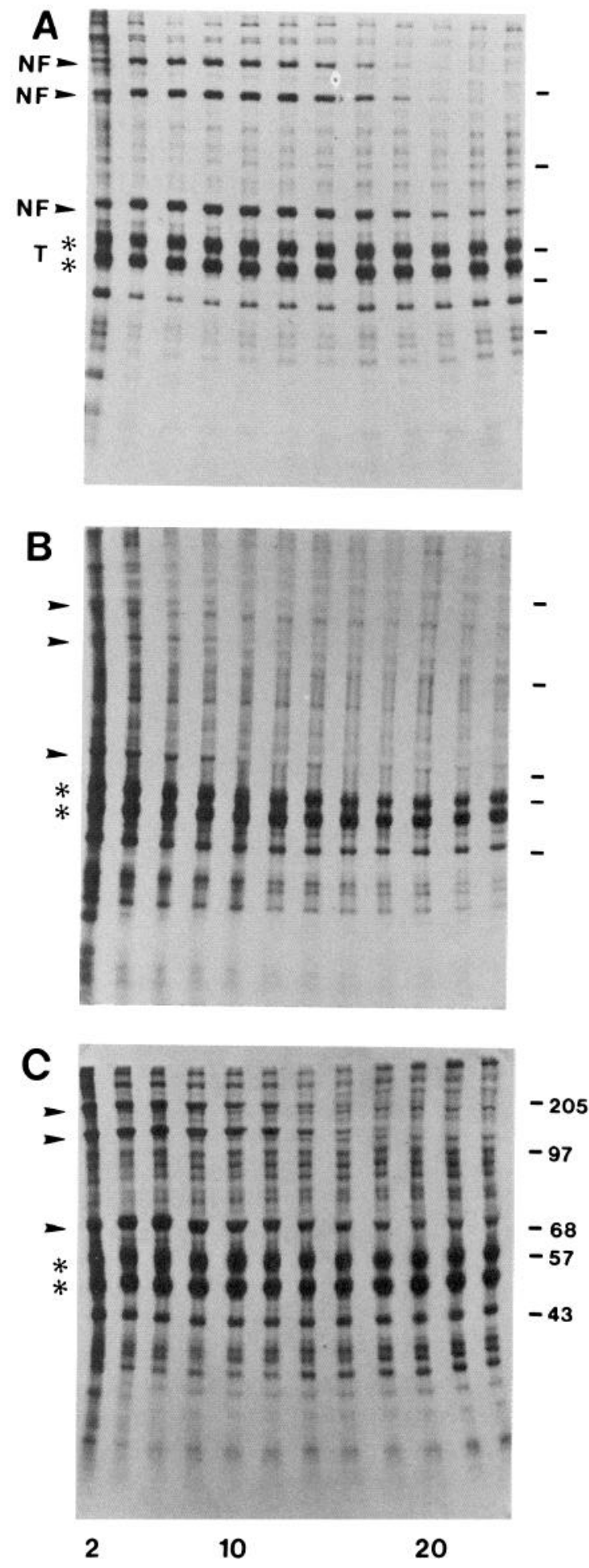

nerve crush condition. The DRG in this experiment was labeled 2 weeks after a distal crush (50-55 mm from the DRG) of the sciatic nerve. $C$, Distal central crush condition. The DRG in this experiment was labeled 2 weeks after a distal crush (28-30 mm from the DRG) of the dorsal root. The positions of the 200,145 , and $68 \mathrm{kDa}$ NF proteins are indicated by arrowheads; tubulins are indicated by asterisks. Numbers on the bottom of the gels represent distance (in mm) from the L5 DRG that the nerve samples were located. The positions of molecular-weight standards are indicated by dashes to the right of each gel panel. Note that a marked reduction in the transport of labeled NF proteins occurs in the peripheral axotomy condition, but not in the central axotomy condition. 


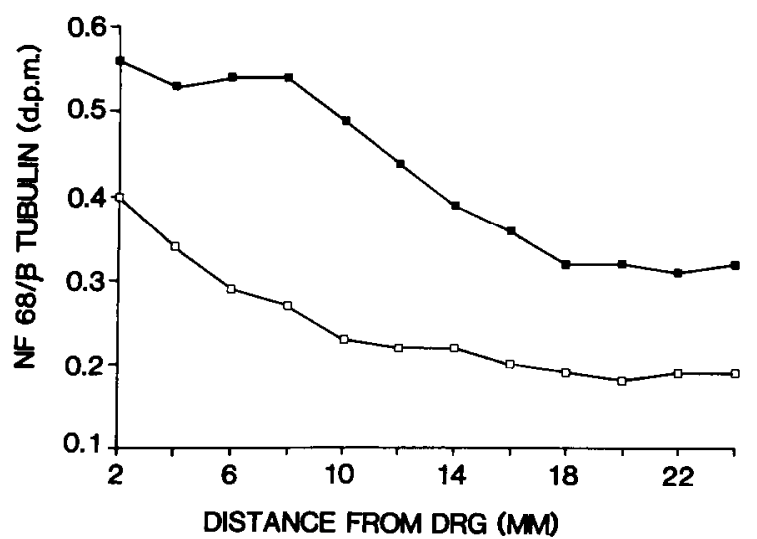

Figure 5. Quantitation of NF/tubulin transport in normal peripheral branch axons and in peripheral branch axons after distal peripheral crush axotomy. Samples were obtained $7 \mathrm{~d}$ after labeling the L5 DRG with ${ }^{35} \mathrm{~S}$-methionine. The mean ratios of radioactivity in NF68 relative to beta-tubulin in successive $2 \mathrm{~mm}$ nerve segments of the sciatic nerve are plotted. Proteins were isolated by PAGE/fluorography, excised from gels, and counted. Normal axons are indicated by solid squares $(n=6)$, and axons in the distal peripheral crush condition $(n=3)$ are indicated by open squares. The peripheral axotomy group of animals was labeled 2 weeks after a crush lesion was made on the sciatic nerve $50-55 \mathrm{~mm}$ from the L5 ganglion.

preparation. Peaks for the other 2 NF subunits behaved identically (not shown). From a number of such experiments, the NF transport rate in normal peripheral DRG axons was estimated to be $1-1.5 \mathrm{~mm} / \mathrm{d}$; in normal $\mathrm{L} 5$ dorsal root axons, this rate was $0.5-1 \mathrm{~mm} / \mathrm{d}$. Quantitation also demonstrated that greater amounts of labeled NF protein were transported into peripheral than into central branch DRG axons (Fig. 3), a finding that was generally true for other slowly transported proteins.

\section{Effects of axotomy on cytoskeletal protein transport in peripheral $D R G$ axons}

The effects of axotomy on protein transport in peripheral branch DRG axons were studied by labeling L5 DRGs 2 weeks after injury to either the sciatic nerve or the dorsal root and examining labeled proteins present in intact regions of peripheral branch axons 1 or 2 weeks after labeling. For example, in the distal peripheral crush condition, the axotomy was done at $50-55 \mathrm{~mm}$ from the L5 DRG and transport was examined in the stretch of axon proximal to this site. Fluorographs of labeled proteins present in peripheral DRG axons 1 week after labeling in normal, distal peripheral crush, and distal dorsal root crush conditions are presented in Figure 4. Visual analysis of fluorographs revealed that the number of labeled NF proteins entering peripheral branch DRG axons was reduced after distal peripheral nerve crush (compare Fig. 4, $A$ and $B$ ). Major changes in the amount of tubulin in $\mathrm{SCa}$ in intact regions of peripheral branch axons were not noticeable after distal peripheral nerve crush (Fig. 4, $A, B$ ).

The reduction in labeled NF protein transport in peripheral branch axons after distal peripheral axotomy was quantified by excising labeled proteins from gels and determining their radioactivity (Fig. 5). The mean ratios of labeled NF68:beta-tubulin in a number of $2 \mathrm{~mm}$ samples of peripheral branch axons (4-16 $\mathrm{mm}$ from the DRG) were significantly lower in the distal peripheral crush condition than in the normal condition at $7 \mathrm{~d}$ after labeling (Fig. 5). Very similar results were obtained by normalizing the amount of labeled NF proteins to total protein

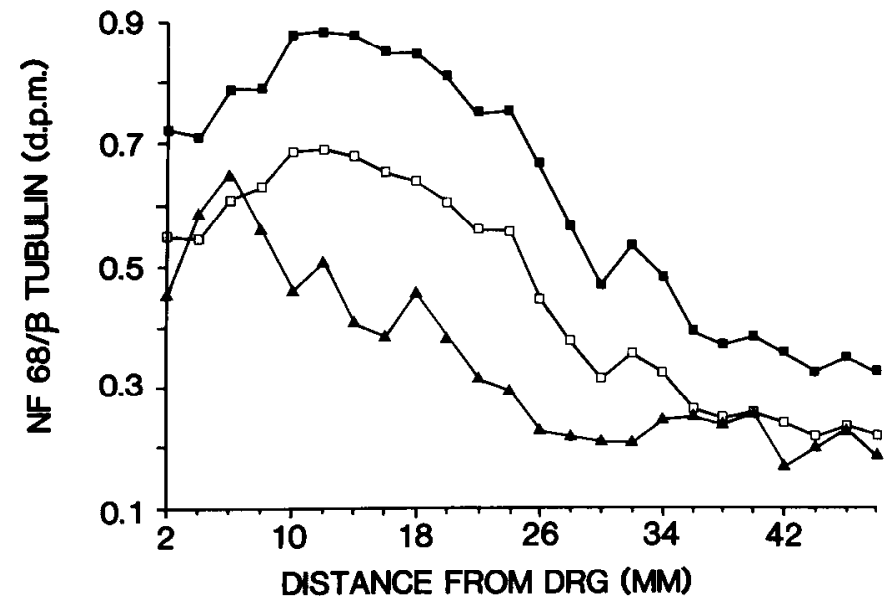

Figure 6. Quantitation of NF/tubulin transport in normal peripheral branch DRG axons and in peripheral branch axons after either distal crush or cut axotomy of the sciatic nerve. Samples were obtained $14 \mathrm{~d}$ after labeling the L5 DRG with ${ }^{35} \mathrm{~S}$-methionine. The mean ratios of radioactivity in NF68 relative to beta-tubulin in successive $2 \mathrm{~mm}$ nerve segments of the sciatic nerve are plotted. Proteins were isolated by PAGE/fluorography, excised from gels, and counted. Normal axons are indicated by solid squares $(n=4)$; axons in the distal peripheral nerve crush condition $(n=6)$ are indicated by open squares; and axons in the distal peripheral nerve cut condition $(n=2)$ are indicated by closed triangles. For both axotomy groups, the DRGs were labeled 2 weeks after the distal axotomies (50-55 $\mathrm{mm}$ from the $\mathrm{L} 5$ ganglion). Note the reduction in labeled NF:tubulin ratios in the crush axotomy group; a more substantial reduction occurred in the cut axotomy group.

radioactivity rather than to beta-tubulin (data not shown). This indicated that the reduced ratios were due to a selective reduction in the amount of labeled NF protein.

At $14 \mathrm{~d}$ after labeling, the NF:tubulin ratios in peripheral DRG axons that sustained a distal peripheral crush lesion were also reduced as compared to normal (Fig. 6). A number of these differences were significant (nerve samples at the peak of the SCa wave located $10-24 \mathrm{~mm}$ from the DRG). Figure 6 also illustrates that distal cut axotomy of the sciatic nerve had a more pronounced effect on the NF/tubulin output into peripheral DRG axons than did distal crush injury. NF:tubulin ratios in peripheral branch axons after distal sciatic nerve cut were significantly lower than those in normal axons in many samples (10-30 $\mathrm{mm}$ from the DRG). It was also apparent that the peak of the labeled NF/tubulin wave was closer to the DRG in the distal peripheral nerve cut condition than normal (Fig. 6). This would be consistent with either a delay in the entry of labeled NF proteins into peripheral axons or a slowing of the rate of NF transport after distal peripheral cut axotomy.

The effect of dorsal root axotomy on transport in peripheral DRG axons was in marked contrast to that of peripheral axotomy. Visual examination of fluorographs of labeled proteins present in peripheral DRG axons $7 \mathrm{~d}$ after labeling DRGs in animals that had sustained a distal injury of the L5 dorsal root $14 \mathrm{~d}$ earlier did not reveal any differences from normal axons (compare Fig. 4, $A$ and $C$ ). Quantitation of gels substantiated this, since no significant differences in the labeled NF:tubulin ratios were found in peripheral branch axons after either distal or close crush of dorsal root axons (Fig. $7, A, B$ ). Very similar results were obtained by normalizing the amount of labeled NF proteins to total protein radioactivity rather than to beta-tubulin (data not shown). 


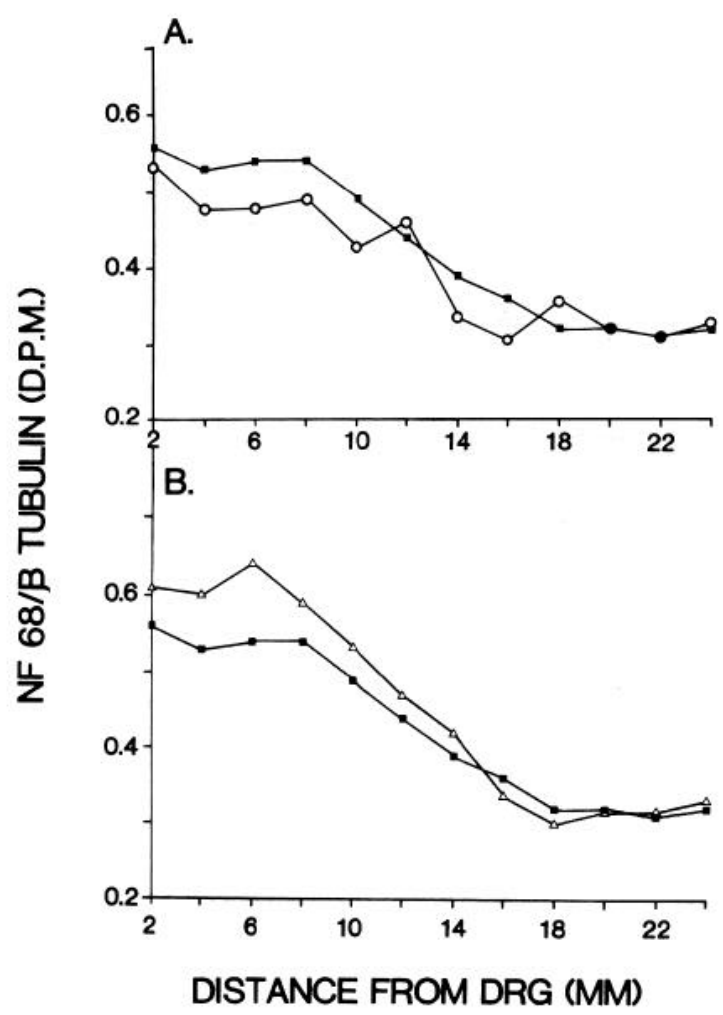

Figure 7. Quantitation of NF/tubulin transport in normal peripheral branch DRG axons and in peripheral axons following central branch axotomy located either close to or far from the DRG. Samples are from axons obtained $7 \mathrm{~d}$ after labeling the L5 DRG with ${ }^{35} \mathrm{~S}$-methionine. The mean ratios of radioactivity in NF68 relative to beta-tubulin in successive $2 \mathrm{~mm}$ nerve segments of the sciatic nerve are plotted. Proteins were isolated by PAGE/fluorography, excised from gels, and counted. Normal axons are indicated by solid squares $(n=6)$ and compared with $(A)$ axons in the distal central crush condition $(n=3)$, indicated by open circles, or $(B)$ axons in the close central crush condition $(n=3)$, indicated by open triangles. The central axotomy groups of animals were labeled 2 weeks after crush lesions were made on the dorsal root at either 2-3 or $28-30 \mathrm{~mm}$ from the L5 ganglion.

\section{Effects of axotomy on cytoskeletal protein transport in central branch DRG axons}

The effects of axotomy on slow transport in central branch DRG axons were studied by labeling L5 DRGs 2 weeks after axotomy of either the sciatic nerve or the dorsal root and harvesting dorsal root axons 2 weeks after labeling. Again, transport was examined only in intact regions of axons. Since the distal central axotomy site was located $28-30 \mathrm{~mm}$ from the L5 DRG, the segment of uninjured dorsal root proximal to this region was used. Fluorographs showing labeled proteins transported in dorsal root axons in 3 conditions are shown in Figure 8. By visual examination, normal axons (Fig. 8A), central branch axons after distal peripheral branch crush (Fig. $8 B$ ), and central branch axons after distal central branch crush (Fig. $8 C$ ) had very similar transport profiles.

Quantitation of gels revealed that distal peripheral branch crush axotomy had no significant effect on the labeled NF:tubulin ratio present in dorsal root axons at $14 \mathrm{~d}$ after labeling (Fig.

Figure 8. Fluorographs of labeled proteins present in consecutive 2 mm segments of central branch DRG axons $14 \mathrm{~d}$ after labeling the L5
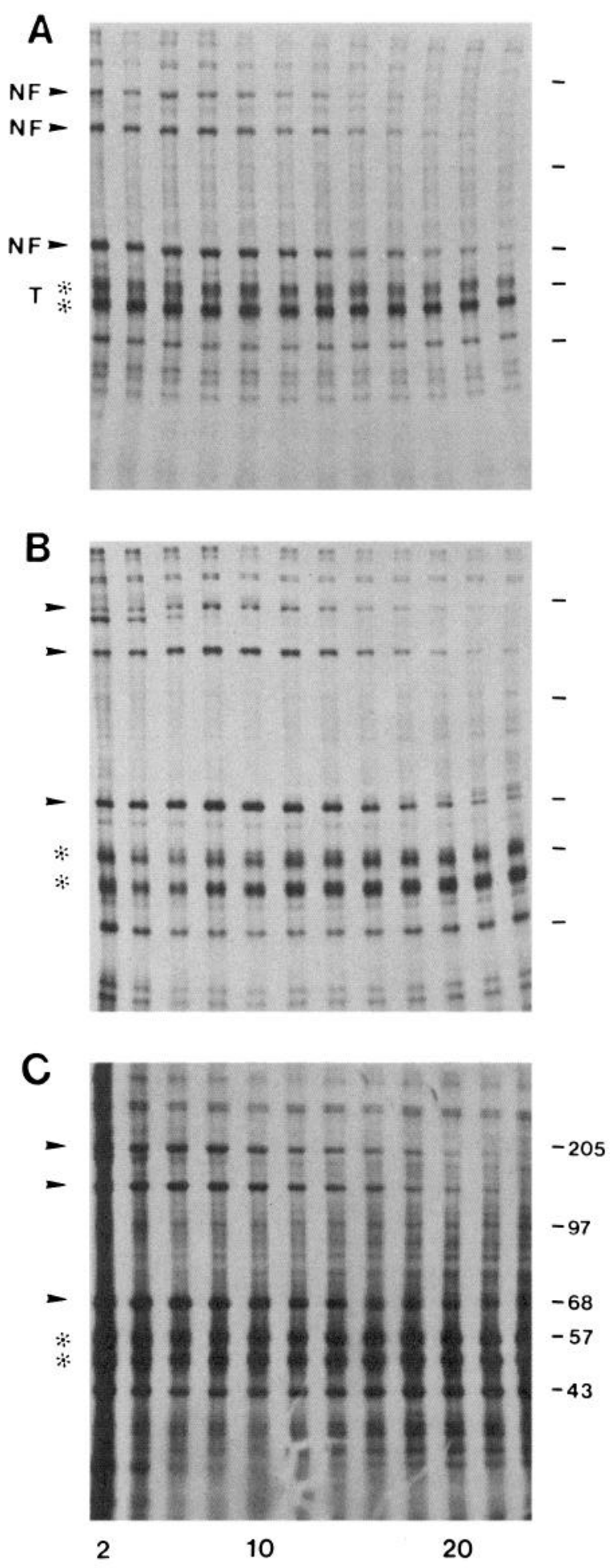

DRG with ${ }^{35}$ S-methionine. $A$, Normal system. $B$, Distal peripheral nerve crush condition. The DRG in this experiment was labeled 2 weeks after a distal crush (50-55 mm from the DRG) of the sciatic nerve. $C$, Distal central crush condition. The DRG in this experiment was labeled 2 weeks after a crush of the dorsal root was made $28-30 \mathrm{~mm}$ from the L5 DRG. The positions of the 200,145 , and $68 \mathrm{kDa}$ NF proteins are indicated by arrowheads; tubulins are indicated by asterisks. Numbers on the bottom of the gel represent distance (in $\mathrm{mm}$ ) from the L5 DRG that the nerve samples were located. The positions of molecular-weight standards are indicated by dashes to the right of each gel panel. Note that neither axotomy condition resulted in any apparent change in labeled NF transport in dorsal root axons. 


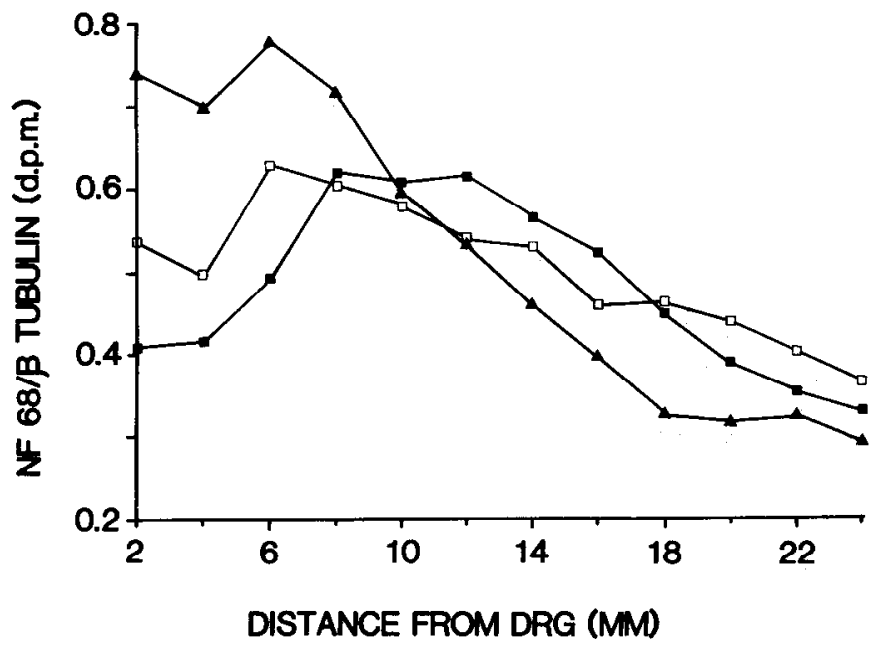

Figure 9. Quantitation of NF/tubulin transport in normal central branch DRG axons in central branch axons following either distal peripheral nerve crush or cut axotomy. Samples are from axons obtained $14 \mathrm{~d}$ after labeling the L5 DRG with ${ }^{35} \mathrm{~S}$-methionine. The mean ratios of radioactivity in NF68 to beta-tubulin in successive $2 \mathrm{~mm}$ nerve segments of the dorsal root are plotted. Proteins were isolated by PAGE/ fluorography, excised from gels, and counted. Normal axons are indicated by solid squares $(n=4)$; axons in the distal peripheral crush condition $(n=6)$ are indicated by open squares; and axons in the distal peripheral cut condition $(n=2)$ are indicated by solid triangles. The axotomy groups of animals were labeled 2 weeks after the cut or crush lesions were made on the sciatic nerve $50-55 \mathrm{~mm}$ from the DRG. No reductions in NF:tubulin ratios are apparent in either axotomy group but the labeling wave appears to be moving more slowly in the axons in the peripheral cut group.

9). Similar results were obtained by normalizing the amount of labeled NF proteins to total protein radioactivity (not shown). However, quantitation revealed that cutting the distal sciatic nerve did have a significant effect on transport in dorsal root axons. In the distal peripheral cut axotomy condition, the NF: tubulin ratios were significantly higher than normal in the first few dorsal root segments (2-6 $\mathrm{mm}$ from the DRG). The position of the peak of the labeled NF/tubulin wave (or the peaks of labeled individual NF proteins; not shown) was closer to the DRG in the distal peripheral nerve cut condition than normal (Fig. 9). The finding that the peak of the labeled NF/tubulin wave was retarded in dorsal root axons after sciatic cut (located at $4-10 \mathrm{~mm}$ ) compared to in normal axons (located 8-14 $\mathrm{mm}$ ) (Fig. 9) is consistent with either a slowing of the transport rate of the NF proteins or a delay in the release of these proteins from the cell body into the axon.

Quantitation of the effects of distal dorsal root crush on transport in dorsal root axons revealed that central branch axotomy $14 \mathrm{~d}$ prior to labeling did not reduce the labeled NF:tubulin ratios present in dorsal root axons (Fig. 10). When the amounts of labeled NF proteins were normalized to total labeled protein in individual nerve segments, no differences between normal central branch axons and central axons after distal dorsal root crush were found (not shown).

\section{Protein synthesis after nerve crush}

Since axonally transported proteins are initially synthesized in neuronal cell bodies, one possible reason for the observed changes in the levels of axonally transported NF proteins in DRG axons is changes in the lcvel of protcin synthesis. To assess whether or not this was the case, protein synthesis in DRG cells was

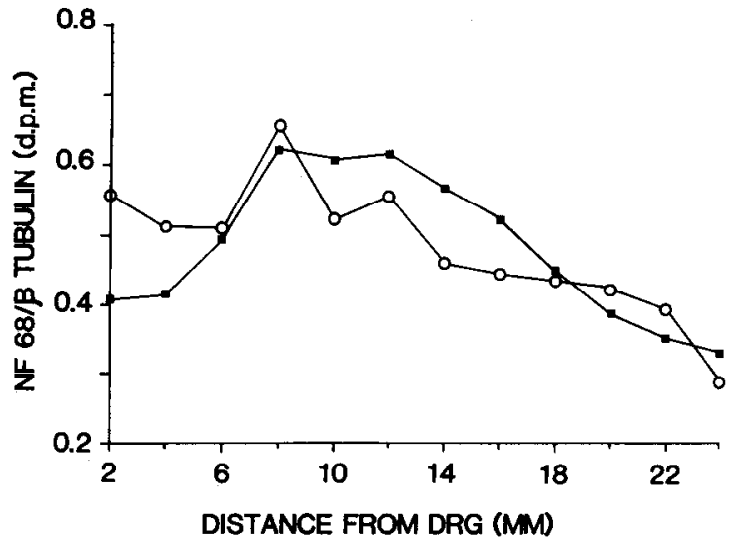

Figure 10. Quantitation of NF/tubulin transport in normal central branch DRG axons and in central branch axons following distal central nerve crush. Samples are from axons oblained $14 \mathrm{~d}$ after labeling the L5 DRG with ${ }^{35}$ S-methionine. The mean ratios of radioactivity in NF68 to beta-tubulin in successive $2 \mathrm{~mm}$ nerve segments of the dorsal root are plotted. Proteins were isolated by PAGE/fluorography, excised from gels, and counted. Normal axons are indicated by solid squares $(n=4)$; axons in the distal central crush condition $(n=3)$ are indicated by open circles. The axotomy groups of animals were labeled 2 weeks after the crush lesions were made on the dorsal root $28-30 \mathrm{~mm}$ from the DRG. No significant differences between the normal and central axotomy groups are present.

compared in normal DRGs and DRGs obtained 1, 5, and $14 \mathrm{~d}$ after distal peripheral branch crush axotomy. Ganglia were removed and incubated with ${ }^{35} \mathrm{~S}-$-methionine in vitro for $1 \mathrm{hr}$. Under these conditions, the specific activity of protein labeling increased with time after axotomy (Fig. 11). To examine the incorporation of ${ }^{35} \mathrm{~S}$-methionine into specific proteins, samples of DRGs were analyzed using 2D gels/fluorography. Examination of fluorographs that were lightly exposed to show only major proteins revealed that the labeling of NF proteins decreased with time after sciatic nerve crush (Fig. 12). A decrease was not visually apparent $1 \mathrm{~d}$ after peripheral branch axotomy, but was noticeable in DRGs labeled 5 and $14 \mathrm{~d}$ after distal sciatic nerve crush (Fig. 12).

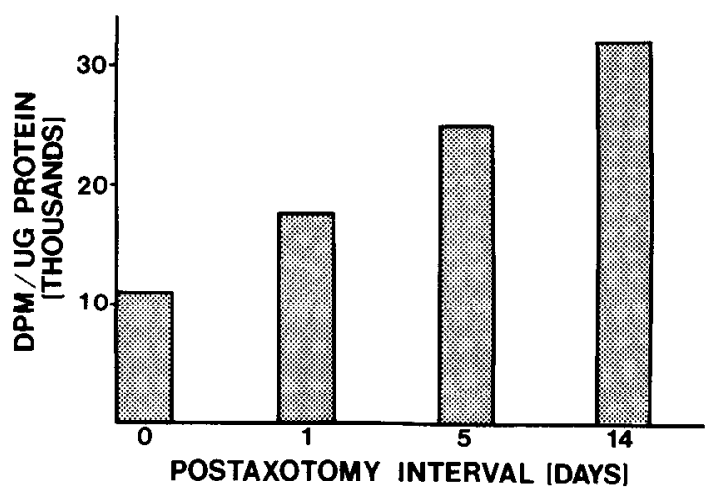

Figure 11. Specific activity of protein labeling in L5 DRGs at various days after distal peripheral crush axotomy. Means of total acid-precipitable radioactivity relative to total ganglionic protein in ganglia labeled at different postaxotomy intervals are plotted. Data were obtained from L5 ganglia labeled in vitro for $1 \mathrm{hr}$ with ${ }^{35} \mathrm{~S}$-methionine. Normal ganglia $(0 \mathrm{~d}, n=6)$ and ganglia obtained $1 \mathrm{~d}(n=3), 5 \mathrm{~d}(n=3)$, or $14 \mathrm{~d}(n=$ 3) after distal sciatic nerve crush are shown. Note that label incorporation increases over control values (day 0 ) with time after peripheral nerve crush. 

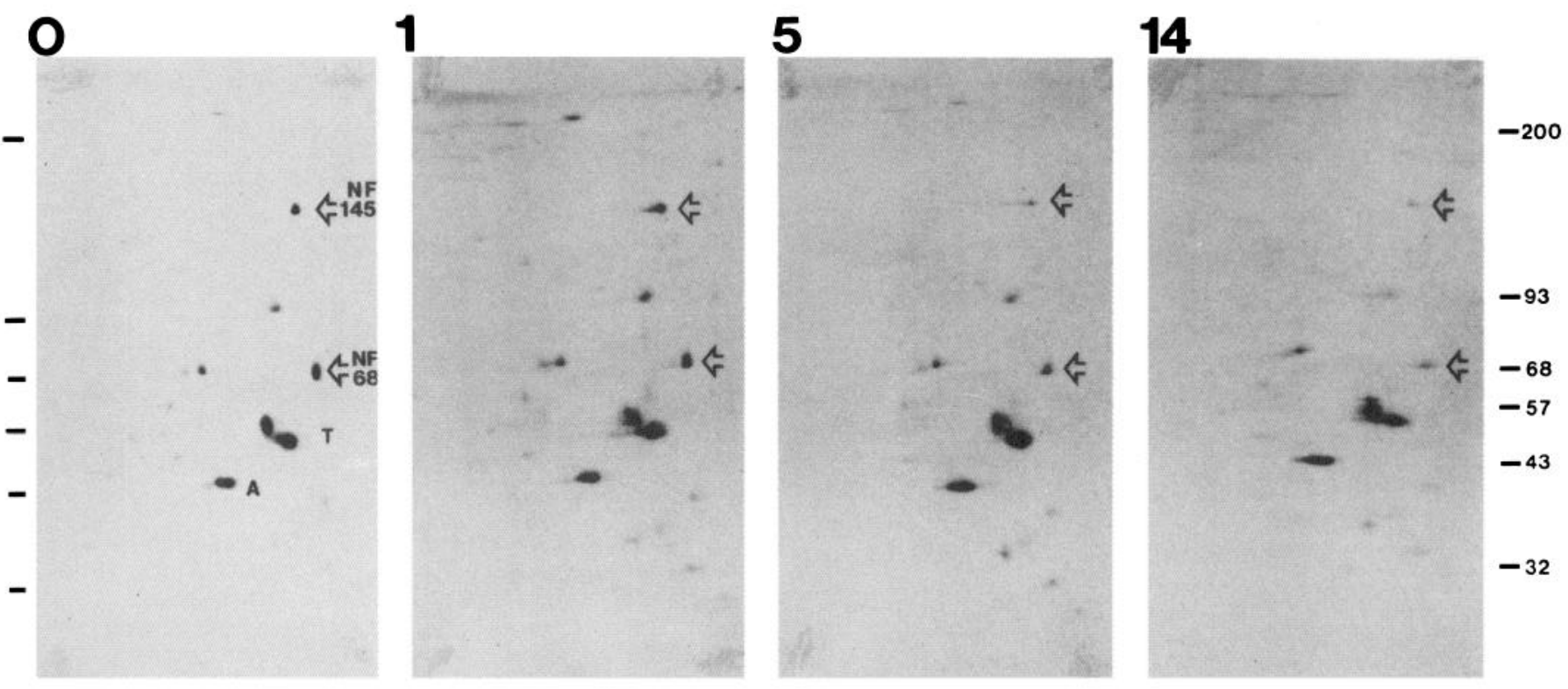

Figure 12. Fluorographs of 2D gels illustrating newly synthesized proteins present in L5 DRGs at different intervals after distal crush axotomy of the peripheral axon. The fluorograph labeled 0 is from a normal DRG; others are from ganglia labeled at 1,5 , or $14 \mathrm{~d}$ after axotomy. Proteins were labeled by incubating L5 DRGs in vitro with ${ }^{35}$ S-methionine for $1 \mathrm{hr}$. Fluorographs were very lightly exposed to visualize only major labeled proteins. Note the progressive decrease in labeling of 2 NF proteins (NF145 and NF68, open arrows) with increasing time after axotomy. Tubulins $(T)$ and actin $(A)$ are also indicated. Bars and numbers at the far right indicate the positions of molecular-weight standards in kilodaltons.

Quantification of 2D gels largely supported the visual observation of reduced NF protein labeling in DRG cells after distal peripheral nerve crush. The radioactivity in NF68 relative to tubulin in DRGs labeled in vitro $14 \mathrm{~d}$ after distal sciatic nerve crush was significantly less than that present in normal DRGs labeled in vitro or in vivo or in contralateral (unlesioned) DRGs labeled in vitro (Fig. 13). The decreased NF:tubulin ratio in axotomized DRGs appeared to be largely due to a decrease in NF synthesis. When the amount of labeled NF68 protein was expressed as a percentage of total labeled protein in the DRG, the $14 \mathrm{~d}$ postaxotomy samples were significantly different from normal (Fig. 14). The slight increase in NF labeling that appeared in a number of samples $1 \mathrm{~d}$ after axotomy (Fig. 14) was not statistically significant, and was observed even in contralateral (unlesioned) ganglia at the $1 \mathrm{~d}$ time point (not shown). As a percentage of total acid-precipitable labeled protein, tubulin was not different from normal at any of the post-crush times examined (Fig. 14).

\section{Discussion}

The results of this study show that, under certain axotomy conditions, adult rat DRG cells differentially alter their output of cytoskeletal polymers to peripheral and central axonal branches. After distal peripheral nerve crush, slow axonal transport in proximal, intact regions of peripheral branch axons conveyed smaller-than-normal ratios of labeled NF protein to tubulin. However, under the same conditions, transport in central branch DRG axons was not different from normal. A more substantial reduction in NF transport in peripheral axons occurred if the distal sciatic nerve was cut rather than crushed. However, under these axotomy conditions, the level of NF/tubulin protein transport in dorsal root axons was still not reduced. Distal peripheral nerve transection did result in an apparent retardation of the movement of the peak of the labeled NF/tubulin wave in both central and peripheral branch sensory axons.
In contrast to the effects of peripheral axotomy, dorsal root crush axotomies positioned either close to or far from the DRG did not produce detectable changes in the transport of cytoskeletal proteins in DRG axons. This finding indicates that the metabolic response of the DRG neurons is dependent on the type and position of the axonal injury. Assessed 2 weeks after axotomy, the DRG cell response is seen to involve a change in the production and transport of the cytoskeleton. However, this metabolic change is manifested only after peripheral axotomy and does not affect all portions of the DRG cell equally. The possible mechanisms and consequences of these observed changes are considered below.

\section{Slow transport alterations follow changes in protein synthesis}

The reduction in the levels of NF proteins transported in peripheral sensory axons after distal peripheral axotomy appears concomitant with a reduction in the synthesis of these proteins in the neuronal cell bodies. Quantitative analysis of 2D gels revealed a significant decrease in the incorporation of labeled methionine into NF proteins relative to total protein during a $1 \mathrm{hr}$ pulse label in DRGs $14 \mathrm{~d}$ after distal peripheral nerve crush. The simplest interpretation of the decreased incorporation of ${ }^{35} \mathrm{~S}$-methionine into NF proteins is that there is a reduced level of synthesis of these proteins. This interpretation is consistent with results of 2 previous studies that examined protein synthesis in rat DRG neurons where peripheral axotomies were positioned very close (several millimeters) to the ganglion (Hall, 1982; Greenburg, 1986). The present findings are also consistent with recent reports that document a reduction in mRNA levels for the NF68 protein in axotomized DRG cells using in situ hybridization with cDNA probes (Hoffman et al., 1987; Wong and Oblinger, 1987). Thus, the observed reduction in axonal transport of NF proteins in peripheral sensory axons after distal peripheral axotomy can, in large part, be attributed to reduced synthesis of NF proteins in the DRG neuronal cell bodies. The 


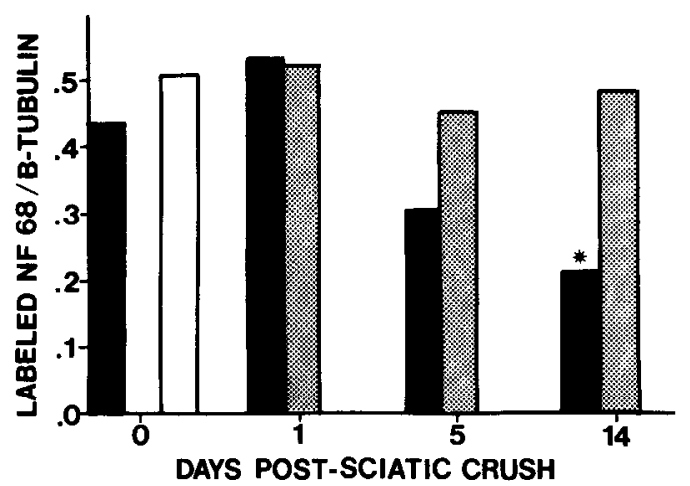

Figure 13. Quantitation of the incorporation of radioactivity into NF68 protein relative to beta-tubulin in normal and peripherally axotomized DRG cells at various intervals after axotomy. In all conditions, L5 DRGs were labeled with ${ }^{35} \mathrm{~S}$-methionine for $1 \mathrm{hr}$ and proteins were separated by 2D PAGE. NF68 and beta-tubulin protein were excised from 2D gels using fluorographs as guides and the radioactivity determined. Solid bars, DRGs labeled in vitro at $0 \mathrm{~d}$ (control, $n=6$ ), $1 \mathrm{~d}$ $(n=3), 5 \mathrm{~d}(n=3)$, or $14 \mathrm{~d}(n=3)$ after distal peripheral nerve crush. Stipled bars, contralateral (not axotomized) DRGs from these same conditions. Open bar, normal DRGs $(n=2)$ that were labeled in vivo.

in situ hybridization studies suggest that the reduced translation of NF proteins may be a consequence of reduced transcription (Hoffman et al., 1987; Wong and Oblinger, 1987).

We did not find a significant difference in the incorporation of labeled methionine into tubulin during a $1 \mathrm{hr}$ pulse label in axotomized DRG cells at any time after peripheral axotomy. This suggests that overall tubulin synthesis was not substantially changed in DRG cells by distal peripheral nerve crush. Previous studies on mammalian axons have noted that axotomy induced decreases in the amount of tubulin transported in SCa (Hoffman and Lasek, 1980), as well as increases in the amount of tubulin transported in $\mathrm{SCb}$ (Hoffman and Lasek, 1980; Oblinger, 1985; McQuarrie, 1986). It is possible that the lack of significant change we observed in radiolabel incorporation into tubulins as a whole was due to a combination of increases and decreases in the production of different tubulins. There are clearly multiple tubulin genes present in the vertebrate genome (Bond et al., 1984; Lewis et al., 1985; Cleveland, 1987). Whether or not the tubulins transported in $\mathrm{SCa}$ versus $\mathrm{SCb}$ are separate gene products has not yet been conclusively established, but it is clear that certain properties of $\mathrm{SCa}$ and $\mathrm{SCb}$ tubulins, such as solubility, differ (Brady and Black, 1986). The gel system used in this study consistently separated only a major alpha- and beta-tubulin. Thus, it is possible that the quantitative data reflect the net change in synthesis of several tubulins that are focused in the same location of the 2D gels (some of which may increase while others decrease). More information on how the expressions of various tubulins change in individual DRG neurons after axotomy might be gained using cDNA probes specific for various tubulins (see Bond et al., 1984).

Tubulin synthesis does appear to significantly increase in rat DRG cells when peripheral nerve crushes or transections are made very close to the ganglion (Hall, 1982; Greenburg, 1986). Additionally, levels of tubulin mRNA assessed by Northern blotting appear to be elevated in the rat DRG when pcripheral crush axotomies are made very close to the ganglion (Hoffman et al., 1987). Thus, another possible explanation for the lack of change in overall tubulin synthesis in our experiments is that

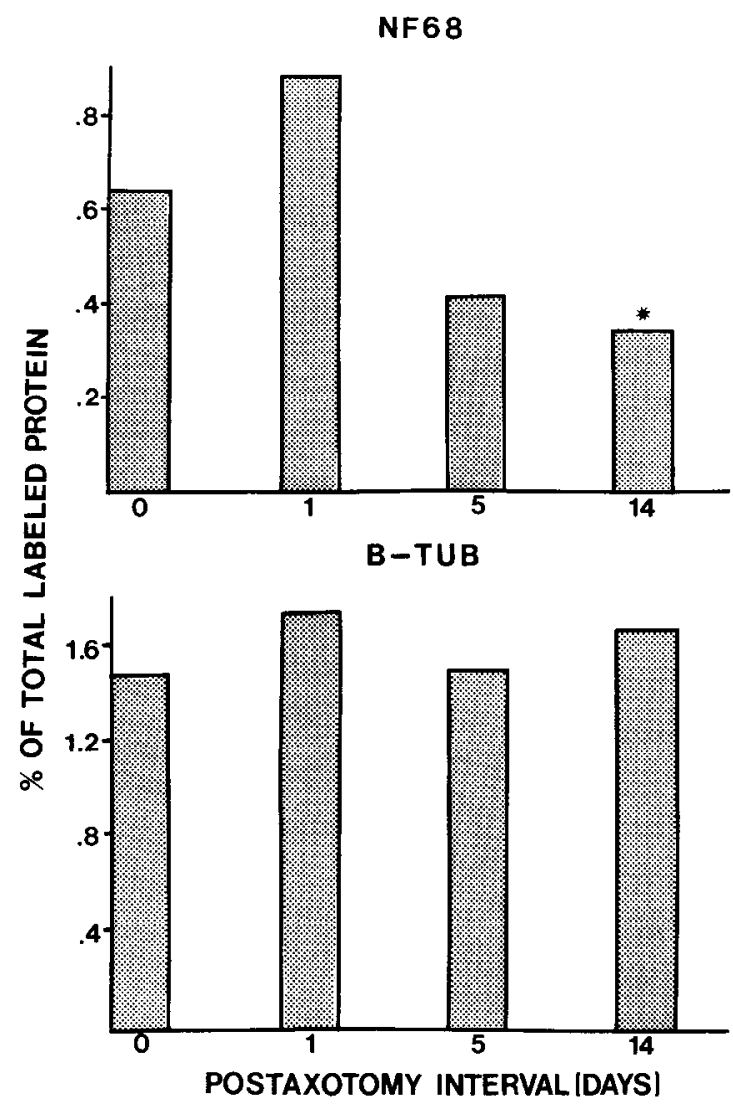

Figure 14. Quantitation of the incorporation of radioactivity into NF68 protein and beta-tubulin relative to total labeled ganglion protein in normal DRGs and in DRGs at various intervals after distal peripheral crush axotomy. All ganglia were labeled in vitro with ${ }^{35} \mathrm{~S}$-methionine for $1 \mathrm{hr}$. After determining the total acid-precipitable counts in aliquots from each sample, the DRG proteins were separated by 2D PAGE/ fluorography. Using fluorographs as guides, NF68 and beta-tubulin proteins were excised from $2 \mathrm{D}$ gels and the radioactivity determincd. Data are from DRGs labeled at $0 \mathrm{~d}$ (control, $n=6), 1 \mathrm{~d}(n=3), 5 \mathrm{~d}(n=$ $3)$, or $14 \mathrm{~d}(n=3)$ after peripheral axotomy. Note that the amount of NF protein labeling relative to total protein synthesis decreases with time after axotomy while tubulin labeling does not.

the distal axotomy site did not generate a stimulus sufficient to elicit changes in tubulin synthesis. This explanation is probably insufficient, since the same axotomy condition did generate a signal that was sufficient to affect NF protein production in DRG cells. In non-mammalian neurons, tubulin synthesis and tubulin mRNA levels have also been reported to increase after axotomy (Heacock and Agranoff, 1976; Neumann et al., 1983; Sinicropi and McIlwain, 1983). Studies of tubulin expression in DRG cells using in situ hybridization still need to be done, but it is clear that the location and type of axotomy will be an important factor in the magnitude of the metabolic response.

\section{Segregation of central and peripheral axonal cytoskeletons in DRG cells}

The consideration of the transport of cytoskeletal proteins in DRG axons in light of the observed changes in protein synthesis after axotomy raises an interesting question: If synthesis of NF proteins in the DRG is reduced after peripheral axotomy, why doesn't the NF:tubulin ratio in slow transport in central branch axons change? A more general version of this question is, How is it that the DRG cell can make a metabolic change that affects 
the composition of one portion of its cytoplasm (its peripheral axon) without significantly altering another (its central axon)? The fact that a selective response can occur is not altogether surprising, since examination of the normal system suggests that some mechanism(s) of selective regulation of the 2 axons is ongoing in DRG cells. For example, in the rat, the central and peripheral axons differ in size (Suh et al., 1984), in the relative proportion of cytoskeletal polymers they contain (Zenker et al., 1975 ), in the rates and quantities of proteins conveyed by slow transport (Mori et al., 1979; Wujek and Lasek, 1983; Oblinger and Lasek, 1985), and in regeneration rate (Komiya, 1981; Wujek and Lasek, 1983; Oblinger and Lasek, 1984). Additionally, we have obscrved that axonal regencration ratc in pcripheral but not central branch DRG axons can be altered by a peripheral conditioning lesion (Oblinger and Lasek, 1984). At this point, the existence of some mechanism(s) in DRG cells that enables differences in the 2 axons to exist and permits a response to be directed to one axon under certain conditions is clear.

We have suggested that organizing centers for synthesis and/ or assembly of axonal cytoskeletons destined for peripheral and central DRG axons are segregated in some fashion in the DRG cell body (Oblinger and Lasek, 1985). If this is indeed the case, it is conceivable that one region could be up- or down-regulated without a significant change in the other region after axotomy. Obviously, under severe conditions that affect the well-being of the entire cell (discussed below), both centers might be affected. Our present findings lend further, albeit indirect, support to the compartmentation model. However, at present we cannot rule out the possibility of other mechanism(s) for routing newly synthesized cytoskeletal polymers into central and peripheral DRG branch axons. Future studies, using high-resolution in situ hybridization methods to examine whether the polysome regions that synthesize NFs for central and peripheral axons are in any way segregated in the cell, may help distinguish between these possibilities.

\section{Conditions of axotomy and magnitude of the neuronal response}

While a selective response has been revealed under the conditions used in the present study, both axons of DRG cells can be severely compromised under more drastic axotomy conditions, such as permanent axotomy or injuries in immature animals. For example, atrophy and degeneration of dorsal root axons and proximal peripheral nerve axons occur after limb amputation (Sunderland, 1978; Carlson et al., 1979; Dyck et al., 1984, 1985). Cutting the peripheral nerve and severely restricting axonal regencration by ligation or resection of a large nerve piece is another strategy that results in atrophy of dorsal root axons and cell death in immature animals (Kingsley et al., 1970; Risling et al., 1980; Aldskogius and Risling, 1981). In adult mammals, such injuries produce less dramatic central effects (Hoffer et al., 1979; Milner and Stein, 1981; Risling et al., 1983; Pfeiffer and Friede, 1985), and the contribution of cell death to the changes is still unclear (Risling et al., 1980, 1983; Sugimoto and Gobel, 1982; Tessler et al., 1985). In the studies cited above, regeneration of sensory axons was essentially nonexistent and, thus, the resulting consequences to protein synthesis and transport would undoubtedly be quite different than those that occurred in the present study, where conditions that favored axonal regeneration were used.

The type and location of an axotomizing lesion are clearly important variables in determining the neuronal response. Even under conditions that result in axonal regrowth, it has long been believed that the effects of nerve cut are more severe than those of nerve crush (Gutmann and Sanders, 1943; Cragg and Thomas, 1961; Sunderland, 1978). The present study lends support to this idea, since cutting the sciatic nerve produced a more dramatic reduction in NF output to peripheral branch DRG cell axons than did crush lesions. The efficiency of axonal regrowth is higher after nerve crush than cut, since many more axons successfully reach their appropriate targets. In our study, many axons would probably have successfully reached their targets after distal peripheral nerve crush because the rate of growth of the leading peripheral DRG axons after nerve crush is about $4 \mathrm{~mm} / \mathrm{d}$ (Wujck and Lasck, 1983; Oblinger and Lasck, 1984). After the same interval in the nerve cut condition, it is likely that most axons would not have elongated to reach a normal target, but would have formed a neuroma instead. Thus, the course and magnitude of the metabolic response to these 2 types of injury are likely to differ because of what happens to the axons subsequent to injury.

Distal peripheral nerve cut produced central effects in our experiments. While the NF:tubulin ratio transported in dorsal root axons was not reduced after transection of the distal sciatic nerve, the position of the labeled NF wave was closer to the DRG than in normal axons. Both a slowing of the rate of transport and a delayed release of newly synthesized proteins from the cell body could produce this effect. With the information made available from the present study, we cannot determine the relative contribution of either of these complex mechanisms, but it is likely that both are active. A delay in the release of NFs from the cell body after axotomy has previously been suggested by observations that an increase in the perikaryal content of NFs occurs after axotomy (Pannese, 1963; Price and Porter, 1972; Torvik, 1976; Moss and Lewkowicz, 1983; Sinicropi and McIlwain, 1983; Drager and Hofbauer, 1984; Goldstein et al., 1987). A slowing of NF transport rate has not been previously documented. However, changes in the transport rate of other proteins (such as the tubulin that moves ahead of the NF front in $\mathrm{SCb}$ ) occur in several types of neurons after axotomy (McQuarrie and Grafstein, 1982; McQuarrie, 1984; Oblinger, 1985). In addition, major changes in both the rate and amount of NF transport are known to occur in development coincident with diameter changes in axons (Hoffman et al., 1983; Willard and Simon, 1983; Pickett and Oblinger, 1986). Further studies are needed to clarify the possible contribution of changes in the rate of release of NFs from the cell body and changes in NF transport rate in axotomized DRG cells.

\section{Changes in axonal transport of cytoskeleton and axonal caliber during regeneration}

Axonal NF content and thus diameter can be influenced by changes in the number of NFs entering the axon and by local changes in the kinetics of transport (Lasek et al., 1983; Hoffman et al., 1985). Both of these types of change appear to occur in the DRG system after distal peripheral axotomy and are likely to have morphological consequences in DRG axons. For example, since the amount of transported NF protein is related to the number of axonal NFs, our findings predict that the diameter of peripheral axons will be compromised by distal peripheral nerve crush, while the diameter of dorsal root axons will be unchanged. Reductions in caliber would first be expected in proximal peripheral axons 2-3 weeks after axotomy, when the altered cytoskeleton moves through proximal portions of 
peripheral axons at a rate of $1-1.5 \mathrm{~mm} / \mathrm{d}$. Distal peripheral nerve cut is likely to result in an even greater reduction in the diameter of peripheral sensory axons, since this condition produces an even greater reduction in the NF:tubulin ratio in axonal transport than does nerve crush.

The situation for dorsal root axons after peripheral nerve transection is more difficult to predict because the observed change was a kinetic one. For example, a change in transport rate may or may not affect all NFs in the axon (the paradigm only allows visualization of the transport of labeled, newly synthesized NFs). If transport of only the newly synthesized NFs were slowed after cut axotomy, an initial proximal-distal thinning of central branch axons might occur as the older NFs were transported distally at a faster rate than that at which the new NFs entered. This situation would clearly be transient and the caliber would again increase as the new NF/MT network continued to enter and move along dorsal root axons.

Hoffman et al. (1987) recently reported that the caliber of both sciatic nerve and dorsal root axons was reduced following sciatic nerve crush, and that the changes occurred much earlier in the sciatic nerve (days) than in the dorsal root (weeks). However, the location of the crush axotomy was much closer to the cell body $(6-7 \mathrm{~mm})$ in that study than in the present study. Further study of the morphological changes that result in both axonal branches of DRG cells after distal and more proximal levels of axotomy under conditions that permit regrowth are needed to clarify the magnitude, time course, and proximodistal progression of any axonal caliber changes that may ensue.

\section{Central axotomy produces a suboptimal signal for eliciting metabolic changes in DRG cells}

In contrast to the dramatic response of DRG cells to peripheral axotomy, our results indicate that the output of labeled NF proteins into the axonal transport system of either central or peripheral DRG axons did not change significantly after central axotomy. We used both a distal (28-30 mm from the DRG) and proximal $(2-3 \mathrm{~mm})$ central crush location in our studies. In all experiments, proteins were labeled 2 weeks after dorsal root crush and transport was studied 1-2 weeks after labeling. Our results are consistent with previous studies that reported that central axotomy did not significantly change protein synthesis in DRG cells (Perry and Wilson, 1981; Hall, 1982; Perry et al., 1983). In fact, significant changes in DRG cell synthesis after dorsal root injury have been reported in only one study, which found the changes to be quite transient (NF synthesis was back to normal by $14 \mathrm{~d}$ after injury; Greenburg, 1986). Our findings are also supported by previous morphological studies of DRG cells that, with very few exceptions, found chromatolysis after peripheral, but not central, axotomy (reviewed in Cragg, 1970; Lieberman, 1971). Additional experiments that address the question of why central axotomy affects the DRG cells' metabolism differently than does peripheral axotomy are obviously needed. These may shed light on the actual molecular signal(s) that elicit aspects of the injury response, such as the downregulation in NF protein production and transport.

\section{References}

Aldskogius, H., and M. Risling (1981) Effect of sciatic neurectomy on neuronal number and size distribution in the L7 ganglion of kittens. Exp. Neurol. 74: 597-604.

Bond, J. F., G. S. Robinson, and S. R. Farmer (1984) Differential expression of two neural cell-specific $\beta$-tubulin mRNAs during rat brain development. Mol. Cell Biol. 4: 1313-1319.
Bonner, W. M., and R. A. Laskey (1974) A film detection method for tritium-labeled proteins and nucleic acids in polyacrylamide gels. Eur. J. Biochem. 46: 83-88.

Brady, S. T., and M. M. Black (1986) Axonal transport of microtubule proteins: Cytotypic variations of tubulin and MAPs in neurons. Ann. NY Acad. Sci. 86: 199-217.

Burrell, H. R., A. M. Heacock, R. D. Water, and B. W. Agranoff (1980) Increased tubulin messenger RNA in the goldfish retina during optic nerve regeneration. Brain Res. 168: 628-632.

Carlson, J., A. C. Lais, and P. J. Dyck (1979) Axonal atrophy from permanent peripheral axotomy in adult cat. J. Neuropathol. Exp. Neurol. 38: 579-585.

Cleveland, D. W. (1987) The multitubulin hypothesis revisited: What have we learned. J. Cell Biol. 104: 381-383.

Cragg, B. G. (1970) What is the signal for chromatolysis? Brain Res. 23: $1-21$.

Cragg, B. G., and P. K. Thomas (1961) Changes in conduction velocity and fibre size proximal to peripheral nerve lesions. J. Physiol. (Lond.) 157: $315 \cdot 327$

Drager, U. C., and A. Hofbauer (1984) Antibodies to heavy neurofilament subunit detect a subpopulation of damaged ganglion cells in retina. Nature 309: 624-626.

Dyck, P. J., H. Nukada, A. C. Lais, and J. L. Karnes (1984) Permanent axotomy: A model of chronic neuronal degeneration preceded by axonal atrophy, myelin remodeling and degeneration. In Peripheral Neuropathy, P. J. Dyck, P. K. Thomas, E. H. Lambert, and R. Bunge, eds., pp. 760-870, Saunders, Philadelphia, PA.

Dyck, P. J., A. Lais, J. Karnes, M. Sparks, and P. J. B. Dyck (1985) Peripheral axotomy induces neurofilament decrease, atrophy, demyelination and degeneration of root and fasciculus gracilis fibers. Brain Res. 340: 19-36.

Goldstein, M. E., H. S. Cooper, J. Bruce, M. J. Carden, V. M.-Y. Lee, and W. W. Schlaepfer (1987) Phosphorylation of neurofilament proteins and chromatolysis following transection of rat sciatic nerve. $J$. Neurosci. 7: 1586-1594.

Greenburg, S. G. (1986) Changes in cytoskeletal protein synthesis during axonal regeneration. Ph.D. dissertation, Case Western Reserve University, Cleveland, $\mathrm{OH}$

Guilian, D., H. Des Ruisseaux, and D. Cowburn (1980) Biosynthesis and intra-axonal transport of proteins during neuronal regeneration. J. Biol. Chem. 255: 6494-6501.

Gutmann, E., and F. K. Sanders (1943) Recovery of fibre numbers and diameters in the regeneration of peripheral nerves. J. Physiol. (Lond.) 101: 489-518.

Hall, M. E. (1982) Changes in synthesis of specific proteins in axotomized dorsal root ganglia. Exp. Neurol. 76: 83-93.

Heacock, A. M., and B. W. Agranoff (1976) Enhanced labeling of a retinal protein during regeneration of optic nerve in goldfish. Proc. Natl. Acad. Sci. USA 73: 828-832.

Hoffer, J. A., R. B. Stein, and T. Gordon (1979) Differential atrophy of sensory and motor fibers following section of cat peripheral nerves. Brain Res. 178: 347-361.

Hoffman, P. N., and R. J. Lasek (1980) Axonal transport of the cytoskeleton in regenerating motor neurons: Constancy and change. Brain Res. 202: 317-333.

Hoffman, P. N., R. J. Lasek, J. W. Griffin, and D. L. Price (1983) Slowing of the axonal transport of neurofilament proteins during development. J. Neurosci. 3: 1694-1700.

Hoffman, P. N., G. W. Thompson, J. W. Griffin, and D. L. Price (1985) Changes in neurofilament transport coincide temporally with alteration in the caliber of axons in regenerating motor fibers. J. Cell Biol. 101: 1332-1340.

Hoffman, P. N., D. W. Cleveland, J. W. Griffin, P. W. Landes, N. J. Cowan, and D. L. Price (1987) Neurofilament gene expression: A major determinant of axonal caliber. Proc. Natl. Acad. Sci. USA 84: 3472-3476.

Kingsley, J. R., G. H. Collins, and W. K. Converse (1970) Effect of sciatic neurectomy on myelinogenesis in the rat spinal cord. Exp. Neurol. 26: 498-508.

Komiya, Y. (1981) Axonal regeneration in bifurcating axons of rat dorsal root ganglion cells. Exp. Neurol. 73: 824-826.

Laemmli, U. K. (1970) Cleavage of structural proteins during the assembly of the head of bacteriophage T4. Nature 227: 680-685.

Lasek, R. J., and P. N. Hoffman (1976) The neuronal cytoskeleton, axonal transport and axonal growth. In Cell Motility, vol. C: Microtubules and Related Proteins, R. Goldman, T. Pollard, and J. Rosen- 
baum, eds., pp. 1021-1051, Cold Spring Harbor Press, Cold Spring Harbor, New York.

Lasek, R. J., M. M. Oblinger, and P. F. Drake (1983) The molecular biology of neuronal geometry: The expression of neurofilament genes influences axonal diameter. Cold Spring Harbor Symp. Quant. Biol. 48: 731-744.

Lewis, S. A., M. G. S. Lee, and N. J. Cowan (1985) Five mouse tubulin isotypes and their regulated expression during development. J. Cell Biol. 101: 852-861.

Lieberman, A. R. (1971) The axon reaction: A review of the principal features of perikaryal responses to axon injury. Int. Rev. Neurobiol. 14: 49-124.

McQuarrie, I. G. (1984) Effect of a conditioning lesion on axonal transport during regeneration: The role of slow transport. In Axonal Transport in Neuronal Growth and Regeneration, J. Elam and P. Cancalon, eds., pp. 185-209, Plenum, New York.

McQuarrie, I. G. (1986) Structural protein transport in elongating motor axons after sciatic nerve crush: Effect of a conditioning lesion. Neurochem. Pathol. 5: 153-164.

McQuarrie, I. G., and B. Grafstein (1982) Protein synthesis and axonal transport in goldfish retinal ganglion cells during regeneration accelerated by a conditioning lesion. Brain Res. 251:25-37.

Milner, T. E., and R. B. Stein (1981) The effects of axotomy on the conduction of action potentials in peripheral sensory and motor nerve fibres. J. Neurol. Neurosurg. Psychiatry 44: 485-496.

Mori, H., Y. Komiya, and M. Kurokawa (1979) Slowly migrating axonal polypeptides. Inequalities in their rate and amount of transport between two branches of bifurcating axons. J. Cell Biol. 82: 174-184.

Moss, T. H., and S. J. Lewkowicz (1983) The axon reaction in motor and sensory 'neurones of mice studied by a monoclonal antibody marker of neurofilament protein. J. Neurol. Sci. 60: 267-280.

Neumann, D., T. Scherson, J. Ginzburg, U. Z. Littauer, and M. Schwartz (1983) Regulation of mRNA levels of microtubule proteins during nerve regeneration. FEBS Lett. 162: 270-276.

Oblinger, M. M. (1985) Regeneration associated changes in axonal microtubule protein transport in dorsal rool ganglion cells of rat. Soc. Neurosci. Abstr. 11: 421.

Oblinger, M. M., and R. J. Lasek (1984) A conditioning lesion of the peripheral axons of dorsal root ganglion cells accelerates regeneration of only their peripheral axons. J. Neurosci. 4: 1736-1744.

Oblinger, M. M., and R. J. Lasek (1985) Selective regulations of two axonal cytoskeletal networks in dorsal root ganglion cells. In $\mathrm{Neu}$ robiology: Molecular Biological Approaches to Understanding Neuronal Function and Development, P. O'I ague, ed., pp. 135-143, Liss, New York.

Oblinger, M. M., S. T. Brady, I. G. McQuarrie, and R. J. Lasek (1987) Cytotypic differences in the protein composition of the axonally transported cytoskeleton in mammalian neurons. J. Neurosci. 7: 453-462.

O'Farrell, P. (1975) High resolution two-dimensional electrophoresis of proteins. J. Biol. Chem. 250: 4007-4024.

Pannese, E. (1963) Investigations on the ultrastructural changes of the spinal ganglion neurones in the course of axon regeneration and cell hypertrophy. Z. Zellforsch. Mikrosk. Anat. 61: 561-586.
Perry, G. W., and D. L. Wilson (1981) Protein synthesis and axonal transport during nerve regeneration. J. Neurochem. 37: 1203-1217.

Perry, G. W., S. R. Krayanek, and D. L. Wilson (1983) Protein synthesis and rapid axonal transport during regrowth of dorsal root axons. J. Neurochem. 40: 1590-1598.

Pfeiffer, G., and R. L. Friede (1985) A morphological study of nerve fiber atrophy in rat spinal roots. J. Neuropathol. Exp. Neurol. 44 . 546-558.

Pickett, J., and M. M. Oblinger (1986) Developmental changes in the neuronal cytoskeleton of pyramidal tract neurons in golden hamsters: Biochemical and immunocytochemical studies. Soc. Neurosci. Abstr. 12: 1231.

Price, D. L., and K. R. Porter (1972) The response of ventral horn neurons to axonal transection. J. Cell Biol. 53: 24-37.

Risling, M., S. Remahl, C. Hildebrand, and H. Aldoskogius (1980) Structural changes in kittens' ventral and dorsal roots L7 after early postnatal sciatic nerve transection. Exp. Neurol. 67: 265-279.

Risling, M., H. Aldoskogius, C. Hildebrand, and S. Remahl (1983) Effects of sciatic nerve resection on $\mathrm{L} 7$ spinal roots and dorsal root ganglia in adult cats. Exp. Neurol. 82: 568-580.

Sinicropi, D. V., and D. L. McIlwain (1983) Changes in the amounts of cytoskeletal proteins within perikarya and axons of regenerating frog motoneurons. J. Cell Biol. 96: 240-247.

Sugimoto, T., and S. Gobel (1982) Primary neurons maintain their central axonal arbors in the spinal dorsal horn following peripheral nerve injury: An anatomical analysis using transganglionic transport of horseradish peroxidase. Brain Res. 248: 377-381.

Suh, Y. S., K. Chung, and R. E. Coggeshall (1984) A study of axonal diameters and areas in lumbosacral roots and nerves in the rat. $J$. Comp. Neurol. 222: 473-481.

Sunderland, S. (1978) Nerves and Nerve Injuries, pp. 82-88, Churchill Livingston, New York.

Tashiro, T., M. Kurokawa, and Y. Komiya (1984) Two populations of axonally transported tubulin differentiated by their interactions with neurofilaments. J. Neurochem. 43: 1220-1225.

Tessler, A., B. T. Himes, N. R. Krieger, M. Murray, and M. E. Goldberger (1985) Sciatic nerve transection produces death of dorsal root ganglion cells and reversible loss of substance $P$ in spinal cord. Brain Res. 332: 209-218.

Torvik, A. (1976) Ceniral chromatolysis and the axon reaction-A reappraisal. J. Neuropathol. Exp. Neurol. 31: 423-432.

Willard, M., and C. Simon (1983) Modulations of neurofilament axonal transport during the development of rabbit retinal ganglion cells. Cell 35: 551-559.

Wong, J., and M. M. Oblinger (1987) Changes in neurofilament gene expression occur after axotomy of dorsal root ganglion neurons. An in situ hybridization study. Metab. Brain Dis. 2: 291-303.

Wujek, J. R., and R. J. Lasek (1983) Correlation of axonal regeneration and slow component $b$ in two branches of a single axon. J. Neurosci. 3: $243-251$

Zenker, W., R. Mayr, and H. Gruber (1975) Neurotubules: Different densities in peripheral motor and sensory nerve fibers. Experientia 31: 318-320. 